\author{
BOARD OF EDITORS \\ BERNARD WEISSBOURD, Editor-in-Chief \\ HAROLD P. GREEN \\ BAXTER K. RTCHARDSON \\ LAWRENCE Howe \\ GEORGE E. WISE
}

DONALD J. YeLLON

DONALD B. CRONSON
ROBERT J. KILPATRICK
JAMES T. LYON
JAMES W. SACK

Associates

James H. Evans, Business Editor

JOSEPH E. SHEEKs, Associate

E. W. PUtTKamaner, Facully Adviser

\author{
ARTHUR H. STMMS \\ ALLEN M. SINGER \\ ALICE F. TRAZNIK \\ IESTER R. URETZ
}

\title{
NOTES
}

\section{TRIAL BY JURY IN INDIRECT CRIMINAL CONTEMPTS}

In I94I the Supreme Court struck two telling blows at the summary power of a judge to punish indirect criminal contempts of court. ${ }^{x}$ Nye v. United States ${ }^{2}$

The conclusions of this note as to the right of trial by jury pertain to all indirect criminal contempts except those which consist of disobedience to any court order or decree. Indirect or constructive contempts are those which are not committed "in the presence of [the] courts, or so near thereto as to obstruct the administration of justice." ${ }_{4}$ Stat. 487 (I83I), 28 U.S.C.A. $\$ 385$ (I928); see Charles Cushman Co. v. Mackesy, I35 Me. 490, 494, 200 Atl. 505, 508 (I938). Criminal contempts are those in which the sentence imposed is not "remedial, and for the benefit of complainant.... [but] punitive, to vindicate the authority of the court." Gompers v. Bucks Stove \& Range Co., 221 U.S. 4I8, 44I (rgII). Although the lines of distinction may become tenuous, as in United States v. United Mine Workers of America, 67 S. Ct. 677 (1947), the above definitions will be satisfactory for the purposes of this note.

= 3 I3 U.S. 33 (I94I). 
effectively removed all indirect contempts except disobedience of court orders from the field of offenses punishable summarily in the federal courts. The full impact of Bridges v. California, ${ }^{3}$ as two subsequent cases have shown, 4 has been to immunize virtually all out-of-court comment on judicial proceedings, whether spoken or written, against citation and punishment as contempt of court. Since such out-of-court comment falls within the scope of the decision in the $N y e$ case, the Bridges decision does not affect the power of the federal courts, but curbs only state court judges. In neither case, however, did the Court consider the crux of the problem: the real flaw in the summary contempt power which has subjected it to constant attack by legal scholars. ${ }^{5}$ Such attack has been leveled primarily at the summary nature of the proceedings - summary in that contemners are tried by a judge alone, without receiving a jury trial. ${ }^{6}$ Critics of the contempt power contend that, since criminal contempts are criminal acts, ${ }^{7}$ constitutional guarantees of trial by jury ${ }^{8}$ should apply to contempt proceedings. Although this right has been universally denied by the courts, research indicates that such denial has been based on extremely dubious authority. ${ }^{9}$ Until the Supreme Court recognizes this fact and includes indirect contempts within the jury trial guarantee, any other limitations of the contempt power such as those established by the $N y e$ and Bridges cases cannot succeed in restricting that power to its proper scope.

In the Nye case, the Supreme Court's primary concern was with the proper construction of the Act of March 2, I83I:

${ }^{3} 3$ I4 U.S. 252 (I94I).

4 Craig v. Harney, 33 I U.S. 367 (I947); Pennekamp v. Florida, 328 U.S. 33 I (I946).

5 C. H. Thomas, Problems of Contempt of Court (I934); Fox, The History of Contempt of Court (I927); J. L. Thomas, The Law of Constructive Contempt (r904); I Livingston, Complete Works on Criminal Jurisprudence 264 (I873); Nelles and King, Contempt by Publication in the United States, 28 Col. L. Rev: 40r, 525 (r928); Frankfurter and Landis, Power of Congress over Procedure in Criminal Contempt in Inferior Federal Courts-a Study in Separation of Powers, 37 Harv. L. Rev. Ioxo (Ig24).

${ }^{6}$ Additional opposition has been directed at the fact that customarily, in the absence of statute, the same judge whose decision has been criticized, or whose authority has been flouted by the contemptuous act, tries the offending party in contempt proceedings. Compare Taft, C. J., concurring in Craig v. Hecht, 263 U.S. 255,279 (I923): "The delicacy there is in the judge's deciding whether an attack upon his own judicial action is mere criticism or real obstruction, and the possibility that impulse may incline his view to personal vindication, are manifest."

I"These contempts are infractions of the law, visited with punishment as such. If such acts are not criminal, we are in error as to the most fundamental characteristic of crimes as that word has been understood in English speech. So truly are they crimes that it seems to be proved that in the early law they were punished only by the usual criminal procedure, 3 Transactions of the Royal Historical Society, N.S. I $_{7}$ (1885), and that at least in England it seems that they still may be and preferably are tried in that way." Gompers v. United States, 233 U.S. 604, 6Io (I9I4).

${ }^{8}$ U.S. Const. Amend. 6 , and similar provisions in state constitutions.

9 Fox, op. cit. supra note 5 ; see Part III, infra. 
Chap. xcix. An Act declaratory of the law concerning contempts of court.

Be it enacted, etc., That the power of the several courts of the United States to issue attachments and inflict summary punishments for contempts of court, shall not be construed to extend to any cases except the misbehaviour of any person or persons in the presence of said courts, or so near thereto as to obstruct the administration of justice. . . . ..$^{20}$

The Act had been passed as the direct result of impeachment proceedings against Judge Peck of the United States District Court of Missouri. II Luke Lawless, unsuccessful counsel in a land grant case before Judge Peck, had published a statement of the errors which he contended the judge had made in his decisiona statement which has been called "as unfair as can be imagined." promptly instituted contempt proceedings and found Lawless guilty, sentencing him to one day's imprisonment and eighteen months' suspension from practicing law. Lawless, a man of no little influence, presented a memorial for Peck's impeachment to Congress, which was acted upon in I830. The House voted to present articles of impeachment, and a long and sensational trial resulted in acquittal by the Senate, twenty-two to twenty-one. Acquittal, however, indicated only that Judge Peck had acted constitutionally in the eyes of Congress; that body acted quickly to dispel any notion that it approved such an exercise of the contempt power by passing the limiting statute quoted above. James Buchanan, leading manager of the impeachment and author of the Act of 1831 , had insisted that no judge in the United States possessed a common-law power to punish summarily, as contempt, any publication regarding judicial proceedings, past or pending, summary punishment being ".... equally at war with the spirit and the letter of the Constitution." 13 This contention as to the existing law of contempt explains the titling of the act as "declaratory" of the law concerning contempt. ${ }^{\mathrm{4}}$

Cases decided shortly after passage of the act construed it in its literal sense, as expressly excluding from summary punishment all publications out of court, whatever their intended or actual effect might be. ${ }^{15}$ Justice Baldwin found the statute's "language too plain to doubt of the meaning of the law, "16 holding that publications out of court could not be considered misbehavior so near the presence of the court as to obstruct the administration of justice, and that

${ }^{\text {Io }} 4$ Stat. 487 (I83I), 28 U.S.C.A. $\$ 385$ (I928).

Ir For complete discussions of the events leading to the impeachment and the proceedings themselves, see Stansbury, Report of the Trial of James H. Peck (1833), and Nelles and King, op. cit. supra note 5 , at 423-3I.

2 Nelles and King, op. cit. supra note 5 , at 428 .

${ }_{3}$ Ibid., at 526 .

${ }^{14}$ Thomas, Problems of Contempt of Court 58 (I934).

${ }_{15}$ Ex parte Poulson, Ig Fed. Cas. I205, No. II,350 (C.C.Pa., I835); United States v. Holmes, 26 Fed. Cas. 360 , No. 15,383 (C.C.Pa., 1842).

${ }^{16}$ Ex parte Poulson, Ig Fed. Cas. I205, No. II,350, at 1207 (C.C.Pa., 1835). 
only "... . misbehavior which is calculated to disturb the order of the court, such as noise, tumultuous or disorderly behavior, either in it or near it" ${ }^{3^{37}}$ was summarily punishable. The additional fact that Justice Baldwin criticized the statute as an unwise exercise of congressional power and would have reached a contrary decision had the statute permitted any other construction, lends weight to the probable validity of his statutory interpretation.

The Supreme Court at first seemed to approve Justice Baldwin's construction, ${ }^{x 8}$ but later the requirement of physical proximity for out-of-court misbehavior was gradually relaxed. ${ }^{x 9}$ The lower federal courts virtually construed the statute out of existence by giving the words "so near thereto" a causal rather than a geographical meaning:

If it is a contempt to bribe a witness in front of the courthouse door, is it not a contempt to do the same thing on the streets opposite the court building, or four blocks away? .... In one case the misbehavior would be construed to be in the presence of the court, and in the other "so near thereto as to obstruct the administration of justice," and the statute, in clear language, is made to apply to both cases."

Finally, in Toledo Newspaper Co. v. United States, ${ }^{2 \pi}$ the Supreme Court affirmed a contempt conviction which was the outgrowth of newspaper publications attacking District Judge Killits and the local traction company in connection with a suit then pending. Its decision not only approved the distorted construction of the Act of I83I, but went far beyond. Chief Justice White first pointed out that "it is essential to recall the situation existing at the time of the adoption of the Act of $183 x$ in order to elucidate its provisions"; 22 then, strangely enough, he ignored history and completely nullified the statute by concluding that ".... there can be no doubt that the provision conferred no power not already granted and imposed no limitations not already existing. In other words, it served but to plainly mark the boundaries of the existing authority resulting from the grants which the Constitution made and the limitations which it imposed." ${ }^{23}$ The defendant was found guilty of contempt. After eighty-seven years the act had indeed become merely "declaratory of the law concerning contempt"-but in a manner to astonish its authors.

Justice Holmes was unable to concur in what has been termed "this

${ }^{27}$ Tbid., at 1208.

${ }^{18}$ See Ex parte Robinson, 19 Wall. (U.S.) 505, 5II (I873): "As thus seen, the power of these courts in the punishment of contempts can only be exercised to insure order and decorum in their presence. ...."

${ }^{x 9}$ Cuddy, Petitioner, $x_{3}$ X U.S. 280 (x889); Savin, Petitioner, x3I U.S. 267,277 (I889); United States v. Anonymous, 21 Fed. 76r, 769 (C.C.Tenn., I884); In re May, I Fed. 737 (D.C.Mich., I880).

${ }^{20}$ In re Brule, 7r Fed. 943, 948 (D.C.Nev., r895); cf. United States v. Huff, 206 Fed. 700, 705 (D.C.Ga., I913); Kirk v. United States, r92 Fed. 273, 277 (C.C.A. gth; rgIr); McCaully v. United States, 25 App. D.C. 404, 4I3 (I905), cert. den. I98 U.S. 586 (I905); Exparte MCLeod, I20 Fed. 130, I37, I39-4I (D.C.Ala., I903).
${ }_{27} 247$ U.S. 402 (IgI8).
${ }^{22}$ Ibid., at $4 \mathrm{I} 6$.
23 Ibid., at 418 . 
amazing historical solecism of the late Chief Justice." 24 He found the limitations imposed by the statute "too plain to be construed away." 25 More important, Justice Holmes dissented on the additional ground that, even if the publications involved justified punishment, contempt proceedings did not furnish the proper form of trial. His dissent rested on a sharp criticism of summary proceedings in indirect contempt cases: .

When it is considered how contrary it is to our practice and ways of thinking for the same person to be accuser and sole judge in a matter which, if he be sensitive, may involve strong personal feeling, I should expect the power to be limited by the necessities of the case "to insure order and decorum in their presence." ... . I would go as far as any man in favor of the sharpest and most summary enforcement of order in Court and obedience to decrees, but when there is no need for immediate action contempts are like any other breach of law and should be dealt with as the law deals with other illegal acts.6

This statement can refer only to ordinary criminal proceedings, which incorporate the right to jury trial. To Justice Holmes, then, the primary objection to the Toledo Newspaper case lay in the denial of trial by jury, and it is this dissent which was subsequently adopted by the Supreme Court in the $N y e$ case.

No publication was involved in the Nye case; defendants were guilty of far more reprehensible conduct than criticizing a judge. By plying a feeble-minded, illiterate old man with liquor, they had induced him to terminate an action for causing the death of his son by use of a patent medicine. As soon as the trial judge discovered these facts, he had cited the defendants for contempt. The Supreme Court overruled the Toledo Newspaper case, holding that since the events had taken place over Ioo miles away from the District Court, they could not be construed as coming under the "so near thereto" clause. The Act of I83I was once again applied in its literal sense, with the Court approving Justice Baldwin's interpretation in the Poulson case. ${ }^{27}$

Confronted with actions which certainly merited punishment, the Court could easily have upheld the conviction; it had only to apply the rule of statutory construction that once the Court has interpreted a statute, it is the function of Congress to alter the act if the interpretation is contrary to legislative intent. However, Justice Douglas expressly rejected such a procedure, saying:

Thus the legislative history of this statute and its career demonstrate that this case presents the question of correcting a plain misreading of language and history so as to give full respect to the meaning which Congress unmistakably intended the statute to have. Its legislative history, its interpretation prior to $19 \pm 8$, the character and nature of the contempt proceedings, admonish us not to give renewed vitality to the doctrine

24 Frankfurter and Landis, op. cit. supra note 5, at rozo.

${ }_{25}$ Toledo Newspaper Co. v. United States, 247 U.S. 402, 423 (rgr8).

${ }^{26}$ Ibid., at 423,425 .

${ }^{27}$ Nye v. United States, 3 I3 U.S. 33, 50 (194I). 
of Toledo Newspaper Co. v. United States, but to recognize the substantive legislative limitations on the contempt power which were occasioned by the Judge Peck episode. And they necessitate an adherence to the original construction of the statute so that unless its requirements are clearly satisfied, an offense will be dealt with as the law deals with the run of illegal acts. ${ }^{28}$

The Court's willingness to overrule the Toledo Newspaper decision cannot be attributed to its desire to uphold the constitutional guarantee of free speech, ${ }^{29}$ as might have been the case had publications been involved in the Nye case. The nature of the offense involved, as well as the reference to dealing with contempts "as the law deals with the run of illegal acts," indicate that the Court's primary concern was once again the right of jury trial in proceedings which are essentially criminal.

Under the Act of 1831 as now interpreted, no judge in the inferior federal courts $^{30}$ possesses the power of summary punishment of any out-of-court misbehavior except acts which may be classified as disobedience of valid court orders. ${ }^{3 \mathrm{I}}$ However, state court judges are not affected by the provisions of the statute. Contempt convictions by state courts can only be appealed to the United States Supreme Court on charges that constitutional rights have been infringed; thus the exercise of the summary power in indirect contempt cases has naturally been attacked as a violation of the Fourteenth Amendment. In Patterson v. Colorado, ${ }^{32}$ the Supreme Court of Colorado had fined the publisher of newspaper articles reflecting on the motives and conduct of that court in cases pending before it. The defendant appealed the conviction on the ground that it infringed the constitutional guarantee of a free press. ${ }^{33}$ Justice Holmes, speaking for the Court, expressly declined to decide whether the Fourteenth Amendment had created a prohibition applicable to the states similar to that which the First Amendment had placed on the federal government, contending that even if it had, the defendant could not prevail. This conclusion was grounded in the Blackstonian theory of liberty of the press: that the constitutional provision was intended only to prevent "laying .... previous restraint upon publications, and not [to grant] freedom from censure for criminal matter when published." 34 Justice Harlan, dissenting, stated that "it would seem clear that when the Fourteenth Amendment prohibited the States from impairing or abridging the privileges of citizens of the United States it necessarily prohibited the States from impairing or abridging the constitutional rights of such

${ }^{28}$ Ibid., at 5 I.

${ }^{29}$ U.S. Const. Amend. I.

${ }^{30}$ For the reason that the statute is said to place no restriction on the justices of the Supreme Court, see text at note 70 infra.

${ }^{3 x}$ The full list of exceptions contained in the statute includes ".... misbehavior of any of the officers of said courts in their official transactions,"and the disobedience or resistance by any such officer, or by any party, juror, witness, or other person to any lawful writ, process, order, rule, decree, or command of the said courts." 4 Stat. 487 (I83I), 28 U.S.C.A. $\$ 385$ (I928).

$$
{ }^{32} 205 \text { U.S. } 454 \text { (I907). } \quad 33 \text { U.S. Const. Amend. I. } \quad{ }^{34} 4 \text { Bl. Comm. }{ }_{15} \text { I. }
$$


citizens to free speech and a free press." ${ }_{35}$ Justice Harlan concluded his opinion with a denunciation of the majority's restrictive construction of the First Amendment. ${ }^{36}$

The Patterson case dissent, anticipating as it did the Bridges case by thirtyfour years, acquired the approval of the Court only gradually. In Schenk $v$. United States,37 Justice Holmes modified his acceptance of Blackstone's theory of liberty of the press, a doctrine since completely repudiated by the Court..$^{8}$ The application of the Fourteenth Amendment to prohibit state encroachments upon freedom of speech and of the press was slower in coming. It was first expressly recognized in 1925,39 and subsequent Supreme Court decisions prior to the Bridges case firmly established the position..$^{40}$ Consequently, foreseeing probable success on that issue, the defendants' appeal from a summary punishment of allegedly contemptuous publications in the Bridges case was based solely on the California court's abridgement of free speech, although denial of the right to trial by jury had been argued below. ${ }^{4 x}$ Split five to four, the Court held that the rights of free speech and a free press necessarily limited the summary "power of all American courts, both state and federal, including this one," ${ }_{42}$ to punish for contempt of court.

In its decision, the majority first rejected the notion that the First Amend-

35 Patterson v. Colorado, 205 U.S. 454, 464 (1907).

${ }^{36}$ "I cannot assent to that view. ... . [If] the rights of free speech and of a free press are, in their essence, attributes of national citizenship, as I think they are, then neither Congress nor any State since the adoption of the Fourteenth Amendment can, by legislative enactments or by judicial action, impair or abridge them..... I go further and hold that the privileges of free speech and of a free press, belonging to every citizen of the United States, constitute essential parts of every man's liberty, and are protected against violation by that clause of the Fourteenth Amendment forbidding a State to deprive any person of his liberty without due process of law." Ibid., at 465 .

37249 U.S. 47 , 5 I (I9I9).

${ }^{38}$ Near v. Minnesota, 283 U.S. 697,7 I $_{4}$ (I93I).

39 "For present purposes we may and do assume that freedom of speech and of the presswhich are protected by the First Amendment from abridgement by Congress-are among the fundamental personal rights and 'liberties' protected by the due process clause of the Fourteenth Amendment from impairment by the States." Gitlow v. New York, 268 U.S. 652, 666 (1925). But see Warren, The New "Liberty" Under the Fourteenth Amendment, 39 Harv. L. Rev. 43 I (I926).

${ }_{10}$ Fiske v. Kansas, 274 U.S. 380,387 (1927); Stromberg v. California, 283 U.S. 359, 368 (I93I); Near v. Minnesota, 283 U.S. 697, 707 (I93I); Grosjean v. American Press Co., 297 U.S. 233, 244 (1936); DeJonge v. Oregon, 299 U.S. 353, 364 (r937); Herndon v. Lowry, 3or U.S. 242, 258 (r937); Lovell v. Griffin, 303 U.S. 444,450 (1938); Hague v. C.I.O., 307 U.S. 496, $5 \times 2$ (1939); Schneider v. State, 308 U.S. I47, 160 (1939); Thornhill v. Alabama, 3 Io U.S. 88, 95 (1940); Carlson v. California, 310 U.S. I06, Ir3 (I940); Cantwell v. Connecticut, 310 U.S. 296, 303 (r940); see Whitney v. California, 274 U.S. 357, 371, 373 (I927); Palko v. Connecticut, 302 U.S. 3 I9, 324, 326 (1938).

${ }_{4}$ Bridges v. Superior Court, $\mathrm{I}_{4}$ Cal. $2 \mathrm{~d} 464,477,94$ P. $2 \mathrm{~d} 983$, $99 \circ$ (x939); Los Angeles Times-Mirror Co. v. Superior Court, I5 Cal. 2d. 99, 102, 98 P. 2d I029, I03I (1940).

\& Bridges v. California, 314 U.S. 252, 260 (I94I). 
ment was not intended to apply to contempt proceedings to punish out-of-court publications pertaining to pending cases, insisting instead that "... the only conclusion supported by history is that the unqualified prohibitions laid down by the framers were intended to give to liberty of the press, as to other liberties, the broadest scope that could be countenanced in an orderly society." 43 Next, the court considered just how broad that scope should be. The California court had followed the Patterson and Toledo Newspaper cases in holding that publications which had a "reasonable tendency" to obstruct the administration of justice in cases pending before a court could be punished as contempt. ${ }^{44}$ The Supreme Court ruled that the "reasonable tendency" test did not afford defendants the full freedom guaranteed by the First Amendment, and that publications are punishable as contempt only when ".... the words used are used in such circumstances and are of such a nature as to create a clear and present danger that they will bring about substantive evils." 45 This "clear and present danger" tes $\mathrm{t}^{46}$ was recognized not as marking "the furthermost constitutional boundaries of protected expression, .... [but] a minimum compulsion of the Bill of Rights." 47 Effectively, then, the summary punishment of a large class of indirect contempts had been severely curtailed.

Justice Frankfurter, representing the four dissenters in the Bridges case, accused the majority of disregarding history by discarding the ancient "reasonable tendency" test; he vehemently denied that punishment for contempt is limited by the First Amendment. $4^{8}$ But the dissenting justices failed to realize

43 Ibid., at 265 .

44 Compare Holmes, J., in Patterson v. Colorado, 205 U.S. 454, 463 (1907): "But if a court regards, as it may, a publication concerning a matter of law pending before it, as tending toward such an interference [with its administration of justice], it may punish it as in the instance put." (Italics added) The Supreme Court adopted the standard in Toledo Newspaper Co. v. United States, 247 U.S. 402, 42 I (I9x): " . . . . not the influence upon the mind of the particular judge is the criterion, but the reasonable tendency of the acts done to influence or bring about the baleful result is the test." (Italics added) The California Supreme Court adopted the "reasonable tendency" standard in Bridges v. Superior Court, I4 Cal. 2d 464, 489, 94 P. 2d 983,996 (I939).

45 Bridges v. California, $3 x_{4}$ U.S. 252, 26I (I94I).

${ }^{6}$ First enunciated by Holmes, J., in Schenk v. United States, 249 U.S. 47,52 (xg19). It was proposed by a minority of the Court as applicable in Abrams v. United States, 250 U.S. 6I6, 627 (IgIg); Schaefer v. United States, 25I U.S. 466, 482 (I920); Pierce v. United States, 252 U.S. 239, 255 (I920); Gilbert v. Minnesota, 254 U.S. 325, 334 (1920); Gitlow v. New York, 268 U.S. 652,672 (1925); and Whitney v. California, 274 U.S. 357,373 (1927) (concurring opinion by Brandeis, J.). Prior to the Bridges case, the majority of the Court had adopted it in Herndon v. Lowry, 3 or U.S. 242, 256 (1937); Thornhill v. Alabama, 3 ro U.S. 88, 105 (r940); Carlson v. California, 3ro U.S. ro6, rr3 (I940); and Cantwell v. Connecticut, 3ro U.S. 296, 308 (1940).

47 Bridges v. California, 3 I4 U.S. 252, 263 (x94I).

48 "But that the conventional power to punish for contempt is not a censorship in advance but a punishment for past conduct and, as such, like prosecution for a criminal libel, is not offensive either to the First or Fourteenth Amendments, has never been doubted throughout this Court's history." Ibid., at 29o. The Blackstonian doctrine of "previous restraints," thought to have been exploded, reappears here. 
that limiting punishment to publications which have a "reasonable tendency to obstruct the administration of justice," as they proposed, also involves recognition of the guarantees of free speech and a free press. If those guarantees did not apply, there would be nothing to prevent a judge from citing as contempt any publication pertaining to courts, even if such publication failed to meet the "reasonable tendency" requirement. Actually the application of the First Amendment is implicit in either standard; the difference between them is one of degree only. Adoption of the "clear and present danger" test merely moves the dividing line between punishable and non-punishable acts farther up the scale of obstructiveness, so that fewer are subject to the summary contempt procedure. The replacement of one test, which had long been considered constitutional, by another seemingly more stringent, discloses more than a concern for freedom of speech. Such a replacement reveals, as in the $N y e$ case, a desire to restrict sharply the use of summary contempt power by judges.

The new test was unanimously approved in Pennekamp v. Florida, 49 another case involving a contempt citation against publications. The uncertainty as to the effect of a state statute empowering the courts to punish indirect contempts summarily, left in doubt by the Bridges case, ${ }^{50}$ was removed completely, since the Court declared that statutes and judicial decisions alike must meet the "clear and present danger" test. The standard itself received no clearer exposition, because the Court again ruled that it had not been met. However, Justice Murphy, in a concurring opinion, declared, "To talk of a clear and present danger arising out of such criticism is idle unless the criticism makes it impossible in a very real sense to carry on the administration of justice."15x Under this view, actual physical obstruction is virtually essential to a contempt punishment, if the contemnor has been able to assert his right of free speech as a curb on the court's power.

Although the majority of the Court would undoubtedly deny that the scope of immunity is so great, its most recent consideration of the problem in Craig v. Harneys2 has brought it close to such a stand. In the Craig case, the Texas Court of Criminal Appeals had applied the Bridges doctrine to newspaper articles sharply critical of a trial judge's decision in a forcible entry and detainer proceeding. A motion for new trial was pending before the same judge, whose place on the bench was elective, and the newspaper involved was extremely influential. Hence the Texas court had concluded that there was in fact a clear and present danger that the publications involved would accomplish their purpose of compelling the judge to change his decision on the pending motion, and that ".... the likelihood that such result would follow was 'extremely serious and 4928 U.S. 33 I (r946).

so Bridges v. California, 3I4 U.S. 252, 260 (194I). The Florida court had distinguished the Bridges case on this basis in Pennekamp v. State, $x 56$ Fla. 227, 24I-44, 248, 22 So. $2 \mathrm{~d} 875,883-$ 84,886 (1945).

sx Pennekamp v. Florida, 328 U.S. 33r, 370 (I946).

${ }^{52} 33$ U.S. 367 (1947). Justice Murphy restated his views in a concurring opinion at 383 . 
the degree of imminence extremely high.' "'s3 Yet the Supreme Court, applying the same rule to the facts, asserted that ".... it takes more imagination than we possess to find in this rather sketchy and one-sided report of a case any imminent or serious threat to a judge of reasonable fortitude." ${ }_{54}$ Justice Frankfurter, in a strongly worded dissent, condemned the majority view as failing to give sufficient weight to the decision of the state court, and in so doing, decried Justice Murphy's stand. ${ }^{55}$ But more important is the fact that two so violently opposed positions can be produced by a single set of circumstances. A few sentences in Justice Frankfurter's opinion unwittingly point to the proper solution: "Surely a jury could reach such a conclusion on these facts. We ought not to allow less leeway to the Texas Court in drawing inferences than we would to a jury. Because it is a question of degree, the field in which a court, like a jury, may 'exercise its judgment is necessarily a wide one." " ${ }_{56}^{6}$ The Supreme Court has shown its concern over the lack of jury trial in indirect contempt proceedings in the $N y e$ and Bridges decisions; it has established a standard which is applied by a jury in all other cases. ${ }^{57}$ What has prevented the seemingly logical adoption of the procedure of trial by jury in this class of cases?

\section{II}

Between 1855 and the r94I decision in the Nye case, virtually all American courts successfully resisted any attempts to limit their powers to punish summarily for contempt, whether the attempted limitation was legislation enumerating the acts so punishable, or setting up the procedural safeguard of jury trial for the contemner. This resistance by the courts has been explained as a product of "the energy with which men, judges included, seek power as power, and the personal weakness and sensitiveness of judges as human beings." ${ }^{38}$ Whatever the reason may be, appellate courts have proved extremely skillful in the devices used to preserve their contempt power. In the absence of legislation governing contempt proceedings, the legal basis for summary punishment is found in the "inherent power" of the court, justified by the necessity of assuring the efficient administration of justice, and supported by "immemorial" usage." 39 If statutory obstacles have been raised, courts have selected one of two

${ }^{53}$ Ex parte Craig, I93 S.W. $2 \mathrm{~d}$ I78, I89 (Tex., I946). For a statement of the facts, see ibid., at $180-84$.

54 Craig v. Harney, 33I U.S. 367,375 (I947).

ss "If .... the Texas Court here was not justified in [its] finding, . . . . clear and present danger' becomes merely a phrase for covering up a novel, iron constitutional doctrine. Hereafter the States cannot deal with direct attempts to influence the disposition of a pending controversy by a summary proceeding, except when the misbehavior physically prevents proceedings from going on in court, or occurs in its immediate proximity. Only the pungent pen of Mr. Justice Holmes could adequately comment on such a perversion of the purpose of his phrase." Ibid., at 39 r.

${ }^{56} \mathrm{Tbid}$, at 390 .

${ }^{58}$ Nelles and King, op. cit. supra note 5, at 544 .

57 Cases cited note 46 supra.

${ }^{59}$ But as to "inherent power" and "immemorial usage," see Part III infra. 
courses: (I) construing the statutes so as to render them useless, as the Supreme Court did in the Toledo case, by holding them merely "declaratory," not limitative, and hence not restrictive of the courts' "inherent power"; (2) declaring the statutes unconstitutional to the extent that they attempt to curtail that same "inherent power."

But this resistance did not appear until half of the nineteenth century had passed. The Act of $183 \mathrm{I}$ represented what was considered at the time an unquestionably valid exercise of legislative power. It had been antedated by legislation in Pennsylvania ${ }^{60}$ and New York ${ }^{6 x}$ growing out of abuses of the contempt power ${ }^{62}$ similar to that which had caused the attempted impeachment of Judge Peck. Other states modeled their legislation on the New York, Pennsylvania, and federal statutes until, in 1855 , more than two-thirds of the states had enacted limitations on the summary power to punish indirect contempts, either by a "so near thereto" clause or by a provision that certain enumerated acts, "and no others," should be punishable as contempt. The constitutional validity of the legislation went unquestioned; ${ }^{63}$ furthermore, the courts respected legislative intent by denying the power to punish publications as contempt..$_{4}{ }^{6}$ This respect may have been due to consciousness of the possible consequences had the judiciary attempted to run counter to the current of legislative thought. ${ }^{65}$ Whatever its origin, however, the respect undeniably existed.

Then, in State v. Morrill, ${ }^{66}$ the Supreme Court of Arkansas denied the power of the legislature to limit the contempt power. A newspaper article implied that the Supreme Court had been induced to make a decision by bribery. Under the statute, declaring that the summary power should apply to certain acts "and no others," ${ }^{367}$ the publication clearly was not subject to punishment as contempt; but the court held that the attempt to limit the scope of the court's power was

60 Pa. Acts (I808-9) c. 78.

${ }^{6 x}$ N.Y. Rev. Stat. (1828), Part iii, c. iii, tit. 2, art. I $\S$ Io.

${ }_{62}$ Respublica v. Oswald, I Dall. (Pa.) 3 I9 (I788); Hollingsworth v. Duane, I2 Fed. Cas. 359, No. 6,6r6 (C.C.Pa., 1801); United States v. Duane, 25 Fed. Cas. 920, No. 14,997 (C.C.Pa., 180I); United States v. Wayne, 28 Fed. Cas. 504, No. 16,654 (C.C.Pa., I801); Respublica v. Passmore, 3 Yeates (Pa.) $44 \mathrm{I}$ (I802); Case of J. V. N. Yates, 4 Johns. (N.Y.) 317 (I80g). Full discussion of these cases may be found in Nelles and King, op. cit. supra note 5, at 409-22.

$6_{3}$ Weaver v. Hamilton, 47 N.C. 343 (I854); State v. Blocker, $x_{4}$ Ala. 450 (I848); Harrison v. Missouri, to Mo. 686 (I847); Commonwealth v. Deskins, 4 Leigh (Va.) 685 (I834).

64 Ex parte Hickey, 4 Smedes \& M. (Miss.) 75x (1845); Stuart v. People, 3 Scam. (IIl.) 395 (1842); Ex parte Poulson, I9 Fed. Cas. I205, No. Ir,350 (C.C.Pa., I835).

${ }_{65}$ Like the Lawless case, both Respublica v. Oswald, I Dall. (Pa.) 319 ( I 788) and Respublica v. Passmore, 3 Yeates (Pa.) 44I (I802) resulted in nearly successful impeachments of the judges who had exercised the contempt power. "It was touch and go whether impeachment would not become an established procedure for taking the judges of a defeated party out of politics." Nelles and King, op. cit., supra note 5 , at 4I4. Apparently the present-day sanctity of the judiciary was far from established, and a judge might think twice before controverting a clear expression of legislative intent on such a controversial issue.

${ }^{66} 16$ Ark. 384 (1855).

${ }^{67}$ Ark. Dig. Stat. (English, I848) c. 36 I. 
unconstitutional. 68 "... . Every enlightened jurist in the United States, who has treated of the subject, has held that the power to punish for contempts, is inherent in courts of justice, springing into existence upon their creation, as a necessary incident to the exercise of the powers conferred upon them." ${ }^{369}$ Since the power to punish contempts was superstatutory, and not the result of legislative grant, it could not be the subject of legislative curtailment. Thus the federal statute was distinguished on the basis that the only constitutionally created federal court was the Supreme Court; the district and circuit courts, having been created by Congress, are subject to Congressional control of the contempt power. Under this interpretation, the Act of I83I places no limitation on the power of the Supreme Court to punish for contempt. ${ }^{70}$ The Arkansas court concluded that the summary power, founded as it was on "immemorial usage," infringed neither the right to trial by jury nor the rights of free speech and a free press; and therefore that the court could punish in contempt proceedings the publisher of a libelous article pertaining to pending or past judicial proceedings.

State v. Morrill has been extremely influential in shaping the subsequent rulings of other state courts; although only a few other courts recognize contempt as a remedy against publications concerning concluded proceedings, ${ }^{7 \mathrm{I}}$ even those which limit the scope of punishable publications to statements affecting pending cases follow the rationale of the Morrill case closely. The decisions of the California court which ruled on the Bridges case are typical. In I8gr, the California legislature had provided:

.... But no speech or publication reflecting upon or concerning any court or officer thereof shall be treated or punished as a contempt of such court unless made in the immediate presence of such court and in such a manner as to actually interfere with its proceedings. ${ }^{.2}$

68 "The prohibitory feature of the act can be regarded as nothing more than the expression of a judicial opinion by the Legislature, that the courts may exercise and enforce all their constitutional powers, and answer all the useful purposes of their creation, without the necessity of punishing as a contempt any matter not enumerated in the act. As such, it is entitled to great respect, but to say that it is absolutely binding on the courts, would be to concede that the courts have no constitutional and inherent power to punish any class of contempts, but that the whole subject is under the control of the legislative department; because, if the General Assembly may deprive the courts of power to punish one class of contempts, it may go the whole length, and divest them of power to punish any contempt." State v. Morrill, r6 Ark. 384,39 I (r855).

69 Ibid., at 390 .

$7^{\circ}$ Although the question of the Supreme Court's power to punish for contempt has never been raised directly, the Court adopted the theory advanced by the Arkansas court in dicta in Michaelson v. United States, 266 U.S. 42, 66 (xg24); Bessette v. W. B. Conkey Co., I94 U.S. 324, 327 (1904); Ex parte Robinson, I9 Wall. (U.S.) 505, 510 ( 1873 ).

${ }^{x}$ In re Fite, II Ga. App. 665, 76 S.E. 397 (IgI2); State v. Hildreth, 82 Vt. 382, 74 Atl. 7 I (rgog); In re Providence Journal Co., 28 R.I. 489, 68 Atl. 428 (I907); Burdett v. Commonwealth, 103 Va. 838, 48 S.E. 878 (I904); State ex inf. Crow v. Shepherd, I77 Mo. 205, 76 S.W. 79 (1903); In re Chadwick, rog Mich. 588, 67 N.W. ro7I (1896); In re Moore, 63 N.C. 397 (I869).

72 Cal. Stat. (I8gI) p. 6, Cal. Code Civ. Proc. (Deering, I897) § I209 (I3). 
However, in In re Shortridge73 a strongly worded dictum declared the statute unconstitutional as an invalid enroachment on the inherent powers of the courts. The language of the decision discloses the court's heavy reliance on the reasoning of the Morrill case:

No authority has been found which denies the inherent right of a court .... to punish as a contempt any act .... which tends to impede, embarrass or obstruct the court in the discharge of its duties..... It is founded upon the principle-which is coeval with the existence of the courts, and as necessary as the right of self-protectionthat it is a necessary incident to the execution of the powers conferred upon the court. ... It exists independently of statute. The legislative department may regulate the procedure and enlarge the power, but it cannot, without trenching upon the constitutional powers of the court, and destroying the autonomy of that system of checks and balances which is one of the chief features of our triple-department form of government, fetter the power itself. 74

Despite the Shortridge decision, the California legislature re-enacted the statute, ${ }^{75}$ only to encounter new declarations of unconstitutionality grounded on identical reasoning. ${ }^{76} \mathrm{~A}$ third re-enactment ${ }^{77}$ met the same fate in the Bridges case..$^{78}$ The struggle for power to control contempt proceedings has been more protracted in California than elsewhere, but the result typifies the situation in the many jurisdictions following the Arkansas doctrine: in the absence of constitutional limitations on the contempt power, the legislature is helpless to limit the courts' use-or abuse-of that power.

In some states, even express constitutional provisions have failed to give the legislature any effective control over punishment for indirect contempts. ${ }^{79} \mathrm{In}$ Arkansas, dissatisfaction with the Morrill decision led to adoption of the state's constitutional provision authorizing legislative control of the contempt power. However, the Arkansas court, by use of a fiction, circumvented the clear language of the constitution and a statute providing that certain acts "and no others" should be punishable as contempt. The court simply ruled that indirect contempts are committed in the constructive presence of the court on the theory that misbehavior is committed where it takes effect, thus bringing such acts

${ }^{73} 99$ Cal. 526, 34 Pac. 227 (1893).

74 Ibid., at 532, 229.

${ }^{75}$ Cal. Stat. (1907) p. 319, Cal. Code Civ. Proc. (Deering, I915) § 1209 (I3).

${ }^{76}$ In re San Francisco Chronicle, I Cal. 2d 630, 634, 36 P. 2d 369, 370 (1934); In re Shuler, 210 Cal. 377, 397, 292 Pac. 48I, 490 (1930).

77 Cal. Stat. (I939) 273I, Cal. Code Civ. Proc. (Deering, I94I) $\$$ I209 (Ir).

${ }_{78}$ Bridges v. Superior Court, 14 Cal. 2d 464, 479, 94 P. 2d 983, 990 (I939).

79 Ark. Const. Art. 7 26: "The General Assembly shall have power to regulate by law the punishment of contempts not committed in the presence or hearing of the courts, or in disobedience to process."

Ga. Const. Art. I $\$$ I par. 20: "The power of the Courts to punish for contempt shall be limited by legislative acts." 
within the constitutional exception. ${ }^{80}$ In Georgia, the constitutional provision was nullified by a strained interpretation. The court construed the constitutional clause as empowering the legislature only to prescribe the punishment after conviction for contempt; hence any attempt to limit the jurisdiction of a constitutional court to punish contempts to certain specified acts exceeds the legislative power and is not binding on the courts. ${ }^{8 \mathrm{r}}$ Under the "inherent power" theory of contempt, then, the courts' power is not only superstatutory, but it may be superconstitutional. A weapon of this nature, unchecked and virtually unlimited, furnishes ample justification for the Supreme Court's action in the Bridges case.

The "inherent power" doctrine has been equally effective in denying a jury trial to contemners. All American courts have uniformly held that, lacking any statute on the subject, no right to trial by jury exists in the federal courts under the Sixth Amendment, or in the state courts, either under the Fourteenth Amendment or under state constitutional provisions. ${ }^{82}$ Because of these holdings, coupled with the use of contempt proceedings to punish violations of labor injunctions, particularly in the Debs and Gompers cases, ${ }^{8_{3}}$ Congress attempted to curb the summary power of the federal courts with the Clayton Act. ${ }^{84}$

Despite the narrow scope of the limitation provided by the Clayton Act and similar statutes, the courts reacted with customary hostility. The Supreme Judicial Court of Massachusetts declared a similar act unconstitutional in Walton Lunch Co. v. Kearney, ${ }^{85}$ relying on the Morrill case and its "inherent

${ }^{80}$ Weldon v. State, r $_{50}$ Ark. 407,234 S.W. 466 (I92I) (altercation between litigant and judge at bathing resort while court was in recess held contempt in constructive presence of court); Turk v. State, I23 Ark. 34I, I85 S.W. 472 (I9I6) (intimidation of litigant before reaching courthouse held punishable as contempt "in presence of court"). The constructive presence device to avoid the limiting effect of a federal type contempt statute was first stated in a dictum in Stuart v. People, 3 Scam. (IIl.) 395,405 (I842), and was adopted by the Illinois court as controlling in People v. Wilson, 64 Ill. r95, $2 \times 1$ (I872).

${ }^{8 x}$ Cobb v. State, 187 Ga. 448, 200 S.E. 796 (I939); Bradley v. State, Ixx Ga. I68, 36 S.E. 630 (I900).

82 "If it has ever been understood that proceedings according to the common law for contempt of court have been subject to the right of trial by jury, we have been unable to find any instance of it. It has always been one of the attributes-one of the powers necessarily incident to a court of justice- that it should have this power of vindicating its dignity, of enforcing its orders, of protecting itself from insult, without the necessity of calling upon a jury to assist it in the exercise of this power." Eilenbecker v. District Court of Plymouth County, I34 U.S. 3I, 36 ( 1890 ); cf. 50 C.J.S. Juries $\S 79$ ( $x 947) ; 35$ C.J. Juries $\S 99$ (r924).

${ }^{8}$ In re Debs, 158 U.S. 564 (1895); Gompers v. United States, 233 U.S. 604 (I9I4).

${ }_{84} 38$ Stat. 738 (Igr4), 28 U.S.C.A. $\$ 387$ (rg28), providing for a jury trial upon demand of defendant in a limited class of contempt cases. In order to fulfil the requirements of the statute, the trial had to be (I) for indirect criminal contempt (2) for violation of an injunction (3) where the act complained of was also a statutory crime.

${ }_{85}$ " 'The summary power to commit and punish for contempts tending to obstruct or degrade the administration of justice is inherent in courts.... as essential to the execution of their powers and to the maintenance of their authority, and is part of the law of the land, within the meaning of Magna Charta and of the twelfth article of our Declaration of Rights.' 
power" doctrine. Although the United States Supreme Court held that the section of the Clayton Act which granted jury trial to criminal contemners was constitutional, ${ }^{86}$ its decision relied on the statute's application only to indirect contempts which were also crimes, and on the power of Congress to regulate the lower federal courts. ${ }^{87}$ The opinion not only failed to repudiate the "inherent power" theory, but approved it. ${ }^{88}$ Since most courts in the state judicial systems are created by the state constitutions, the Michaelson case does not furnish a guide to constitutionality in state courts. ${ }^{89}$ Nor does it lend comfort to broader statutes like the Norris-LaGuardia Act, ${ }^{90}$ which provides for trial by jury in all indirect contempt cases based on any violation of a labor injunction..$^{9 x}$

Although the only two appellate courts which have ruled directly on the validity of Norris-LaGuardia type statutes have ruled in their favor, it is significant that the courts were those of Pennsylvania92 and New York,93 the states with the oldest statutes limiting punishment for contempt. In both states, the power of the legislature to curb the jurisdiction of courts in contempt cases has been long recognized and acquiesced in; accordingly, additional checks on the contempt power have more chance for success. But the most important feature of the cases is the brilliant concurring opinion of Justice Maxey of the Pennsylvania Supreme Court in the Pennsylvania Anthracite Mining case, an opinion which won approval by the New York Appellate Division.94 Justice Maxey blasted the "inherent power" theory as "something akin to the divine right of

... [ [ $\mathrm{It}]$ is beyond [the] power of Legislature to curtail jurisdiction of courts over contempts. ... . Any statute requiring a jury trial upon contempt proceedings would be substantial im-, pairment of the inherent right of courts to maintain their authority." 236 Mass. $3 \times 0,3 \times 5-17$, I 28 N.E. 429, 431-32 (1920).

${ }^{86}$ Michaelson v. United States, 266 U.S. 42 (1924).

${ }^{87}$ See text at note 70 supra.

88 "That the power to punish for contempts is inherent in all courts, has been many times settled and may be regarded as settled law. .... . So far as the inferior Federal courts are concerned, however, it is not beyond the authority of Congress [citing cases]; but the attributes which inhere in that power and are inseparable from it can neither be abrogated nor rendered practically inoperative. That it may be regulated within limits not precisely defined may not be doubted. The statute now under review is of the latter character. It is of narrow scope, dealing with the single class where the act or thing constituting the contempt is also a crime in the ordinary sense." 266 U.S. 42, 65, 66 (xg24).

89 Fort v. Cooperative Farmers' Exchange, 8I Colo. 43I, 256 Pac. 3Ig (I927), held a jury trial statute unconstitutional, distinguishing the Michaelson case on these grounds.

${ }^{90} 47$ Stat. 72 (I932), 29 U.S.C.A. § IrI (1947).

9* The Massachusetts court declared that such a statute would be unconstitutional without mentioning Michaelson v. United States in In re Opinion of the Justices, 275 Mass. 580, 176 N.E. 649 (193r).

92 Pennsylvania Anthracite Mining Co. v. Anthracite Miners of Pennsylvania, 3 I8 Pa, 40I, I 78 Atl. 29I (1935).

93 Kronowitz v. Schlansky, 156 N.Y. Misc. 717, 282 N.Y. Supp. 564 (1935).

94 Ibid., at $721,569$. 
kings. ... . [which] has been repudiated by modern juristic scholarship." $95 \mathrm{He}$ dismissed the distinction between constitutional and statutory courts as "very much overdone," declaring that neither type of court possessed such inherent power. Finally, he presented an argument which, even accepting the "inherent power" doctrine, destroys the validity of objections to jury trial statutes: "Another fallacy .... is that the act .... takes away from the court the right to punish for disobedience to its process. What is taken away is only the right of the judge whose order the respondent is accused of disobeying, to determine unaided by a jury the fact of disobedience. .... The word 'court' and the word 'judge' are not synonymous, and to require a judge to share with a jury the administration of justice does not take away power from 'a court.' " 96

Unfortunately, there are too few Justice Maxeys and too few courts willing to adopt his reasoning. Despite their validity, these arguments have little effect on the armor with which most courts have encased themselves by repeating the magic formulae of "inherent power" and "immemorial usage." The Virginia Supreme Court, overcoming a constitutional mandate that the legislature should regulate the jurisdiction of the courts, ${ }^{97}$ declared a statute providing for jury trial in contempt cases unconstitutional as violative of the courts' inherent power. ${ }^{98}$ Such superconstitutional power thus invalidates jury trial statutes as well as statutes limiting the acts punishable as contempt. This broad power can only be defeated by proof that it is, in fact, neither "inherent" nor based upon "immemorial usage." And the establishment of such proof requires examination of the modern juristic scholarship to which Justice Maxey referred.

\section{III}

American decisions asserting the validity of summary proceedings in indirect contempt cases have uniformly followed the reasoning of the Morrill case. The Morrill case founded its entire claim as to the ancient origin of summary contempt power on Justice Wilmot's opinion in Rex v. Almon'9 and Blackstone's Commentaries ${ }^{\text {roo }}$-the earliest statements of that power. As a result, the extrajudicial declaration in Almon's Case, although it cannot carry the binding force of a decision as precedent, has had a more pervasive effect on the law of con-

${ }^{95} 3$ I8 Pa. 40I, 4I3-14, I78 Atl. 29I, 296 (I935).

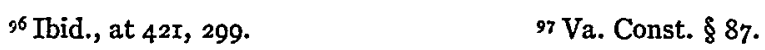

98 "... . [In] the courts created by the constitution there is an inherent power of self-defense and self-preservation; .... this power may be regulated, but cannot be destroyed, or so far diminished as to be rendered ineffectual by legislative enactment; . . . it is a power necessarily resident in, and to be exercised by, the courtitself, and .... the vice of an act which seeks to deprive the court of this inherent power is not cured by providing for its exercise by a jury." Carter v. Commonwealth, 96 Va. 791, 816, 32 S.E. 780, 785 (189g).

99 Due to a formal error in the entitling of the rule nisi, which caused abandonment of the case, this opinion was never delivered. It was first published thirty-seven years later, after its author's death, in Wilmot, Notes of Opinions and Judgements 243 (I802).

${ }^{100} 4$ Bl. Comm. ${ }^{*} 83$. 
tempt than any other single statement. It is probable that Blackstone's discussion of the summary contempt procedure stems directly from Justice Wilmot's undelivered decision: there is a marked resemblance in phraseology and content between the opinion, written in $I 765$, and the corresponding section of the Commentaries, published in I769; the portion of the Commentaries dealing with attachment for contempt does not stem from Blackstone's lectures as Vinerian Professor, as does the remainder of his work; and it is known that Blackstone submitted proofs of part of the Commentaries to Wilmot for the latter's examination. ${ }^{\text {rox }}$ Thus the profound influence of Blackstone on the American law of contempt ${ }^{\text {ro2 }}$ can be traced to the ubiquitous Rex $v$. Almon.

The passage in which virtually the entire present-day law of contempt finds its origin is as follows:

The power which the courts in Westminster Hall have of vindicating their own authority is coeval with their first foundation and institution; it is a necessary incident to every court of justice, whether of record or not, to find and imprison for a contempt to the court, acted in the face of it, and the issuing attachments by the supreme courts of justice in Westminster Hall for contempts out of court stands upon the same immemorial usage as supports the whole fabric of the common law; it is as much the lex terrae and within the exception of Magna Charta as the issuing any other legal process whatever. I have examined very carefully to see if I could find out any vestiges or traces of its introduction but can find none. It is as ancient as any other part of the common law; there is no priority or posteriority to be discovered about it and therefore cannot be said to invade the common law, but to act in an alliance and friendly conjunction with every other provision which the wisdom of our ancestors has established for the general good of society. And though I do not mean to compare and contrast attachments with trial by jury, yet truth compels me to say that the mode of proceeding by attachment stands upon the very same foundation and basis as trial by juries do-immemorial usage and practice. ${ }^{103}$

If true, this statement would furnish complete substantiation for the stand which American courts have taken-but it is completely lacking in truth.

Sir John Fox, investigating the English history of contempt I 50 years later, made the startling discovery that Wilmot's claim of the ancient origin of summary procedure in indirect contempt cases was entirely groundless. Fox disclosed the results of his research in a series of law review articles, ${ }^{104}$ which he

sox Fox, op. cit. supra note 5 , at 2 I.

${ }^{203}$ "The meagreness of American law libraries contributed, of course, to account for the almost Scriptual authority of Blackstone in our early law." Nelles and King, op. cit. supra note 5 , at 405 n. 25 .

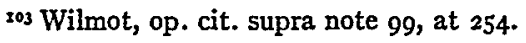

ro1 The King v. Almon, 24 L. Q. Rev. I84, 266 (Ig08); The Summary Process to Punish Contempt, 25 L. Q. Rev. 238, 354 (I909); Eccentricities of the Law of Contempt of Court, 36 L. Q. Rev. 394 (I920); The Nature of Contempt of Court, 37 L. Q. Rev. IgI (I92I); The Practice in Contempt of Court Cases, 38 L. Q. Rev. 185 (1922); The Writ of Attachment, 40 L. Q. Rev. 43 (r924). 
later revised, expanded, and published in book form. ${ }^{\text {xos }}$ Briefly stated, his conclusion was that all indirect criminal contempts, except those alleging disobedience of court orders, were always tried by a jury until $x$ 72I, and that the innovation of summary procedure in the largest group of indirect criminal contempts was far from well established at the end of the eighteenth century. Prior to the reign of Queen Elizabeth, all indirect criminal contempts had been tried by indictment or information; then the Star Chamber introduced the procedure of examination upon interrogatories without a jury. When that court was abolished, the King's Bench resumed its former procedure until Rex $v$. Barber, ${ }^{\mathrm{ros}}$ in which an irate Chief Justice, wishing to punish for words contemptuous of the court, adopted the Star Chamber methods. Only nine other cases, including Rex v. Almon, can be found using the summary procedure before $1800 .{ }^{107}$ In the Court of Chancery, no indirect criminal contempts were tried by any method whatever until the abolition of the Star Chamber. After that court ceased to exist, such cases were tried only by information in the King's Bench or on the common-law side of Chancery until I742. Then, in Roach v. Garvan ${ }^{x 08}$ Lord Hardwicke established the practice of punishing this class of contempts by summary procedure, a process followed in only one other Chancery case during the eighteenth century. ${ }^{109}$

In cases involving disobedience of court orders or decrees, Fox's research indicated that here, too, criminal contempts were prosecuted solely in jury proceedings until the Star Chamber inaugurated the use of attachments and interrogatories. ${ }^{\text {ro }}$ Thus any decision which denies the validity of a statute granting a jury trial in criminal contempt proceedings to parties who have violated injunctions, and which bases that denial on the ground that the statute violates a court's "necessary and inherent power," is clearly erroneous. Since no other valid objection has been raised to such statutes, jury trial provisions similar to those in the Clayton and Norris-LaGuardia Acts should receive uniform declarations of constitutionality. However, the fact that summary punishment of disobedience of court orders had become the usual practice by the time the United States Constitution was adopted precludes any claim that, in the absence of statutory provisions, defendants in that class of contempt cases are entitled to trial by jury as of right.

ros Fox, The Fistory of Contempt of Court (1927).

${ }^{206}$ I Strange 444 (I72I). Contra: Rex v. Revel, I Strange 420 (I72x) (when abusive words "are spoken in the presence of the Justice he may commit, but when it is behind his back the party can be only indicted").

${ }^{{ }^{0} 7}$ Rex v. Wilkin, K. B. Easter Term (I722); Rex v. Colbatch, K.B. Easter Term (I723); Rex v. Wiatt, 8 Modern *I23 (I723); Rex v. Middleton, Fortescue 201 (I723); Rex v. Bolton, K.B. Mich. Term (I724); Rex v. Lawley, K.B. Mich. Term (I73I); Rex v. Carroll, I Wilson 75 (I744); Rex v. Almon (1765); Rex v. Steare, 8 How. St. Tr. 60 (I768). For discussion of these cases, see Fox, op. cit. supra note I05, at 25-6, III-I5.

${ }^{108} 2$ Atkyns 469 (1742). rog Cann v. Cann, 2 Ves. Sr. 520 (I754).

${ }_{2 \times 0}$ Fox, op. cit. supra note I05, at 89,93, I03 -4 . 
In short, then, any attempt to justify the denial of trial by jury in indirect contempts by pointing to "inherent power" based on "immemorial usage" must fail. The United States Constitution adopted trial by jury in the criminal cases in which it existed in $\mathrm{r} 789$; and common-law crimes were recognized at the time the Constitution was ratified. ${ }^{\text {III }}$ At the close of the eighteenth century, summary prosecutions for contempt were not an exclusive remedy; at best, the summary procedure was exercised alternatively with trial by jury. If this fact had been known, there is little doubt that American courts of that time would have included indirect contempt proceedings in the guarantee of the Sixth Amendment. ${ }^{\mathrm{Ir}}$ Since only a historical error prevented that result, the correction of that error by Fox's research should certainly preclude courts from declaring that jury trial statutes for contempt proceedings are unconstitutional. Such statutes merely revert to the true common law, so that their constitutionality should be beyond doubt. Furthermore, courts aware of the error should rule, even without statutes, that defendants in indirect criminal contempt proceedings, if there has been no violation of a valid court order, are entitled to trial by jury as a matter of right.

But aversion to change and the desire to retain power on the part of courts prevent this logical result. Missouri's Supreme Court, ruling on a contempt of court charge for publishing articles criticizing the trial court's conduct in a past case, ${ }^{\mathrm{rr} 3}$ had full knowledge of Fox's work. The court discussed Almon's Case, noted that Wilmot's opinion was probably the foundation of Blackstone's statement of the contempt power, and pointed out that ".... exhaustive historical research in recent years has proved that Wilmot was wrong and that the power he claimed had never been exercised by the common-law courts, but only in a few instances by the court of Star Chamber. Sir John Fox, Contempt of Court, ch. 2." ${ }^{1124}$ Yet the court's conclusion was that although a publication concerning a closed case is not punishable as a contempt of court, a publication concerning a pending case may be so punished. Unfortunately, the court's citation of Fox proved too much for its decision to be valid. Nowhere in his work was any distinction made between criticism of pending and past cases-his conclusions applied with equal strength to both classes. Thus if the court accepted Fox's conclusion that there was no common-law basis for Wilmot's opinion and thereby barred summary punishment of publications relating to closed cases, it could not logically assert the existence of a power of summary punishment for comment on pending cases. However, the practice of "selective citation" allowed the IIx Ex parte Grossman, 267 U.S. 87, $\mathrm{II}_{4}$ (1925).

112 The strong feeling of the times toward the right of jury trial can be seen in one of the charges against King George III in the Declaration of Independence: "He has combined with others to subject us to a jurisdiction foreign to our constitution and unacknowledged by our laws; giving his Assent to their Acts of pretended Legislation .... For depriving us in many cases of the benefits of Trial by Jury."

${ }^{\text {rz }}$ State ex rel. Pulitzer Publishing Co. v. Coleman, 347 Mo. I238, x52 S.W. 2d 640 (1941). sx Tbid., at 1258,647 . 
Missouri court to perpetuate a manufactured distinction which has no foundation in the common law and little foundation in logic.

Other courts have similarly distorted the results of Fox's research in reaching decisions completely opposed to the author's conclusions. ${ }^{\text {rrs }}$ Intelligent opinions both recognizing the significance of Fox's discoveries and applying them correctly to rectify long-established errors have never been handed down by the majority of any court. Justice Maxey's statement in the Pennsylvania Anthracite Mining case was a concurring opinion:;16 Justice Edmonds of the California Supreme Court, arguing against the applicability of summary contempt proceedings in the Bridges case, was forced to dissent. ${ }^{\text {Ir7 }}$ Although it is undeniable that ".... the courts have built a structure of judicial reasoning upon the sands of precedents which do not exist, ${ }^{, 128}$ the problem of razing this structure is not yet solved.

\section{IV}

Despite their attempts to preserve the contempt power intact, courts have always been uneasy because of the summary procedure involved. Even Blackstone, the staunchest upholder of the summary power as necessary to the existence of the courts, admitted that it was ".... not agreeable to the genius of the common law in any other instance." "Ir9 This uneasiness has translated itself into the gradual process of conferring on the contemnor the rights of a defendant in a true criminal proceeding. At first, only notice and a reasonable opportunity to defend ${ }^{\mathrm{I20}}$ were necessary for the validity of the proceedings in any out-ofcourt contempt. The basically criminal nature of the offense and punishment led the federal courts to extend to the alleged contemnor the presumption of innocence, ${ }^{\text {xax }}$ the privilege against self-incrimination, ${ }^{x 22}$ and the requirement that his guilt be established beyond a reasonable doubt. ${ }^{123}$ Finally, Judge Learned

rrs Bridges v. California, 3 I4 U.S. 252, 285-88 (194I) (Frankfurter, J., dissenting); Bridges v. Superior Court, $\mathrm{I}_{4}$ Cal. $2 \mathrm{~d}$ 464, 48I-84, 94 P. 2d 983, 99I-93 (I939).

${ }^{256}$ Note 95 supra.

${ }_{217}$ Bridges v. Superior Court, $\mathrm{r}_{4}$ Cal. $2 \mathrm{~d} 464,494,94$ P. $2 \mathrm{~d} 983,998$ (I939).

${ }^{118}$ Ibid., at 495, 999.

"rg 4 Bl. Comm. ${ }_{287}$.

${ }^{220}$ Taft, C. J., in Cooke v. United States, 267 U.S. 517, 537 (I925): "Due process of law, therefore, in the prosecution of contempt, except of that committed in open court, requires that the accused should be advised of the charges and have a reasonable opportunity to meet them by way of defense or explanation. We think this includes the assistance of counsel, if requested, and the right to call witnesses to give testimony, relevant either to the issue of complete exculpation or in extenuation of the offense and in mitigation of the penalty to be imposed." This rule was applied in Savin, Petitioner, I3I U.S. 267 (1889), which adopted the established procedure in disbarment proceedings as described in Randall v. Brigham, 7 Wall. (U.S.) 523,540 (1868).

${ }^{\text {r2x }}$ Gompers v. Bucks Stove \& Range Co., 22 I.S. 418, 444 (I9II); Western Fruit Growers v. Gotfried, I36 F. 2d 98, I00 (C.C.A. 9th, I943); In re Eskay, I22 F. 2d 8rg, 822 (C.C.A. 3d, I94I); see Michaelson v. United States, 266 U.S. 42,66 (r924).

${ }^{222}$ Cases cited note I2I supra.

${ }^{\text {na3 }}$ Cases cited note I21 supra; In re McIntosh, 73 F. 2d 908, gro (C.C.A. 9th, I934); Sabin v. Fogarty, 70 Fed. 482,485 (C.C. Wash., 1895 ). 
Hand, in McCann v. New York Stock Exchange, ${ }^{\text {r2 }}$ set up the requirement that criminal contempt proceedings must be prosecuted by the United States district attorney or by an attorney appointed by the court; in the latter case, the papers supporting the process must show the criminal nature of the proceeding. ${ }^{25}$ The Supreme Court incorporated all of these protections into Rule 42(b) of the Federal Rules of Criminal Procedure, ${ }^{226}$ so that the defendant is now accorded all the procedural safeguards to which a criminal defendant is entitledexcept trial by jury. Most state courts have also balked at this final step. Until now, the jury trial safeguard has been denied because of the belief that an inherent power of summary punishment existed in this class of cases; with that belief undermined, it is only necessary to find that recognizing the right to jury trial will be a desirable step.

Any discussion of the jury-trial requirement as it applies in the federal courts, of course, would be purely academic. The Act of $183 \mathrm{x}$, as it has been interpreted by the $N y e$ case, removes all out-of-court misconduct of the type with which Fox's investigation dealt from summary punishment as contempt, so that such conduct is punishable only if made a crime by Congressional action. ${ }^{27}$ In the state courts, on the other hand, the Bridges decision precludes any form of punishment of out-of-court publications, whether by summary attachment or in a jury proceeding, unless the publication constitutes a "clear and present danger" to the administration of justice. However, the application of the "clear and present danger" rule by a single judge is, to say the least, not conducive to best results, particularly if the judge is the same one whose conduct has been attacked by the publication. The defendant is forced to pay the costs of an appeal, sometimes to the Supreme Court, with each successive court acting as a jury in its determination of whether the facts meet the standard. It was pointed out earlier that the "clear and present danger" test is applied by a jury in all other cases; ${ }^{x^{28}}$ since social policy, reason, and common law all demand a jury trial in this instance, there seems no basis for denying it.

The universal application of trial by jury in indirect criminal contempts, in light of the state court opposition discussed in Part II, can only be accomplished

22480 F. 2 d $2 I_{1}, 2 x_{4}$ (C.C.A. $2 d, 1935$ ).

${ }^{25}$ The procedure required by Judge Hand was adopted by other circuit courts in Western Fruit Growers v. Gotfried, 136 F. 2d 98, Ior (C.C.A. 9th, I943); In re Eskay, I 22 F. 2d 819, 823 (C.C.A. 3 d, I94I); FTC v. A. McLean and Son, 94 F. $2 d$ 802, 804 (C.C.A. 7th, 1938).

${ }_{226}$ "A criminal contempt except as provided in subdivision (a) of this rule [contempts committed in the actual presence of the court] shall be prosecuted on notice. The notice shall state the time and place of hearing, allowing a reasonable time for the preparation of the defense, and shall state the essential facts constituting the criminal contempt charged and describe it as such.... . The defendant is entitled to a trial by jury in any case in which an act of Congress so provides. .... If the contempt charged involves disrespect to or criticism of a judge, that judge is disqualified from presiding at the trial or hearing except with the defendant's consent." Federal Rule of Criminal Procedure 42(b) following I8 U.S.C.A. \$ 687 (Supp., I946).

${ }_{27}$ United States v. Hudson and Goodwin, 7 Cranch (U.S.) 32 (r8I3).

${ }^{288}$ Cases cited note 46 supra. 
by the United States Supreme Court, and hence only through the medium of the Fourteenth Amendment. It has often been contended that the Fourteenth Amendment was meant by its proponents to apply to the safeguards set out in the Bill of Rights so as to prevent their infringement by the states, and therefore that it should have that effect.129 Although four justices on the present Supreme Court follow such a view, ${ }^{\mathrm{r} 30}$ a majority of the Court has never held that the Fourteenth Amendment incorporates, as such, the specific guarantees found in the first eight amendments. But the assertion that the Fourteenth Amendment requires state courts to grant jury trials in all indirect criminal contempt cases which do not charge disobedience of court orders need not rest solely on the ground that trial by jury in criminal cases is dealt with in the Sixth Amendment. ".... [It] is possible that some of the personal rights safeguarded by the first eight Amendments against National action may also be safeguarded against state action, because a denial of them would be a denial of due process of law..... If this is so, it is not because those rights are enumerated in the first eight Amendments, but because they are of such a nature that they are included in the conception of due process of law." "'3x If the right to jury trial can be shown to be implicit in the concept of due process of law as that concept applies in indirect criminal contempt proceedings, the Fourteenth Amendment must be held to guarantee trial by jury in such cases. Due process of law, in this sense, has been defined as consisting of those settled usages and procedures existing in England before the establishment of our country, which were not in conflict with our political ideals..$^{{ }^{32}}$ And no proceedings can fit that definition more closely than jury trials in indirect criminal contempts, examined in the light of Fox's research. The inevitable conclusion is that the Constitution requires state courts to grant trial by jury to defendants charged with indirect criminal contempts unless they have disobeyed court orders.

Each of the two sharply differing views on the Court as to the scope of the Fourteenth Amendment has criticized the opposing theory's "subjective test." "133

${ }^{129}$ Betts v. Brady, 3 I6 U.S. 455, 474 (1942) (Black, J., dissenting); Twining v. New Jersey, 211 U.S. 78, II4 (rg08) (Harlan, J., dissenting); Maxwell v. Dow, r76 U.S. 58I, 605 (I900) (Harlan, J., dissenting); O'Neil v. Vermont, I44 U.S. 323, 363 (I892) (Field, J., dissenting); Hurtado v. California, I10 U.S. 5I6, 538 (1884) (Harlan, J., dissenting); Slaughter-House Cases, I6 Wall. (U.S.) 36, 83, III, I24 (I872) (Field, Bradley, Swayne, JJ., and Chase, Ch. J., dissenting); Flack, The Adoption of the Fourteenth Amendment 84 ff., 2ro-77 (1908).

${ }^{x} 3^{\circ}$ Adamson v. California, $33^{2}$ U.S. 46, 68-123, 123-25 (I947) (dissenting opinions); Foster v. Illinois, 332 U.S. I34, I39-4I, I4I-45 (I947) (dissenting opinions).

${ }^{\text {x3x }}$ Twining v. New Jersey, 2II U.S. 78, 99 (Igo8); see Powell v. Alabama, 287 U.S. 45, 668 (I932).

${ }_{332}$ Twining v. New Jersey, 2Ir U.S. 78, 100 (rgo8); Holden v. Hardy, 169 U.S. 366, 390 (1898); Hallinger v. Davis, I46 U.S. 314, 320 (I892); Murray's Lessee v. Hoboken Land Co., 18 How. (U.S.) 272,280 (I855).

${ }^{\text {x3 }}$ Compare Justice Frankfurter's defense of "natural law" as the antithesis of "subjective selection" in Adamson v. California, 332 U.S. 46, 65 (1947) with Justice Black's attack on "natural law" as synonymous with "subjective selection," ibid., at 69-70. 
Yet either view, consistently applied, would provide jury trials in constructive criminal contempt cases. Under both theories, due process requires different procedural safeguards in different situations: a prosecution which fulfils the demands of due process in punishing a direct contempt may not suffice if the alleged contempt was committed out of court. ${ }^{\mathrm{x} 34}$ Justice Cardozo, expressing the majority rationale, has suggested that "... we reach a different plane of social and moral values when we pass to the privileges and immunities that have been taken over from the earlier articles of the federal bill of rights and brought within the Fourteenth Amendment by a process of absorption. These in their origin were effective against the federal government alone. If the Fourteenth Amendment has absorbed them, the process of absorption has had its source in the belief that neither liberty nor justice would exist if they were sacrificed." "r35 If this is so, then the climb of our "social and moral values" has been a slow one indeed; even the basic right of freedom of speech was only "absorbed" by the Fourteenth Amendment fifty-seven years after its adoption. ${ }^{136}$

Admittedly, the denial of jury trial in one class of contempt cases is not of the same broad sweep as the denial of free speech or a free press; perhaps it does not stand on the same plane in the scale of civil liberties. But Justice Cardozo's analysis is not exclusive. Unyielding application of the "inherent power" and "immemorial usage" doctrine by state courts has thwarted all legislative attempts to abolish summary proceedings in indirect contempts. Even if it is admitted that the "Fourteenth Amendment did not mean to imprison the States into the limited experience of the eighteenth century, ${ }^{\prime 137}$ application of the jury trial guarantee in this class of cases is preferable to the present self-imposed imprisonment into the more limited experience of the nineteenth century. A declaration by the Supreme Court that due process of law in constructive criminal contempt cases, except those charging violation of court decrees, includes trial by jury would be far better than perpetuating a useless fiction with its roots in one of the least desirable practices of the Star Chamber.

\section{THE SEDITION TRIAL: A STUDY IN DELAY AND OBSTRUCTION}

On January 3, 1944, a federal grand jury in Washington, D.C., returned an indictment charging thirty defendants ${ }^{x}$ with conspiracy, together with officials

${ }^{234}$ See Ex parte Oliver, I6 U.S.L. Week 4240, 4245 (1948).

x35 Palko v. Connecticut, 302 U.S. 319, 326 (1937).

${ }_{236}$ Gitlow v. New York, 268 U.S. 652 (1925).

${ }^{23}$ Justice Frankfurter concurring in Louisiana ex rel. Francis v. Resweber, 329 U.S. 459, 468 (I947); see Adamson v. California, 332 U.S. 46 (r947).

I These were Joseph E. McWilliams, George E. Deatherage, William Dudley Pelley, James True, James Edward Smythe, Lawrence Dennis, Howard Victor Broenstrupp alias Count 